\title{
THE BARÍ LANGUAGE OF VENEZUELA: A GLIMPSE AT THE CHIBCHAN PERIPHERY ${ }^{1}$
}

\section{J. Diego Quesada}

\begin{abstract}
This paper offers a succinct description of the main structural features of Barí, a Chibchan language of Venezuela. This account is the first of its kind, thus contributing to the morphosyntactic description of one more potentially endangered Amerindian language. In the wider context of Chibchan comparative linguistics, a new member of the family is described, with the particularity that it is the easternmost language, and one surrounded by languages from a different linguistic area, Amazonia. This study corresponds to the first stage in the larger process of description and documentation of Barí2.
\end{abstract}

\section{Introduction}

The aim of this paper is twofold. First, it intends to provide the wider scholarly community with data from a hitherto rather scarcely described indigenous language of South America, Barí (Chibchan, Venezuela). Second, the information collected will be analyzed in the light of the existing studies on Chibchan comparative grammar (e.g. QUESADA 1999a, 1999b, 1999c) in order to ascertain whether Barí's status as the easternmost member of the Chibchan family (see Fig. 1) has had any effects on its structure, as it usually happens with "frontier languages" (Barí, in Venezuela, is bounded by Arawak and Cariban languages). The following description of Barí, which will be limited to morphology and syntax (see VIVAS \& OBREGÓN (1989) for a phonological description), corresponds to an early stage of research on this language; hence most of the data are of a rather general nature, with little in-depth analysis and linguistic argumentation, which, of course, remain for further publications on the language. The main concern of the paper is thus to provide the main structural features of Barí in order to have a good point of reference for both Chibchan linguistics and typological studies.

\section{The Barí people}

The Barí people comprise some 2,500 individuals living on both sides of the Colombian-Venezuelan border in the departments of César and Norte de Santander, and the state of Zulia, respectively, at the skirts of the Sierra de Perijá. Due to the well-known armed conflict in Colombia, it is practically impossible to do field work on that side of the

\footnotetext{
${ }^{1}$ In Sprachtypologie und Universalienforschung (Munchen) 2004, 57 (4) 362-376.

${ }^{2}$ This paper is the product of my research activities while as a visiting professor at the Federal University of Rio de Janeiro, which enabled me, among other things, to do field work in Venezuela in 2001. I wish to express my sincere thanks to Marília Facó Soares for her support while in Rio. Special thanks are due to Luis Oquendo for introducing me to the Barí community in Maracaibo, to Lucía Rincón for sharing with me her ethnographic field notes, and to Raymundo Medina, who provided me with some of the existing information on the Barí language. Last but certainly not least, special thanks deserve Leonardo Okiano and Fatima Añandou, both native speakers of Barí, for their invaluable help as language consultants. None of these people should be held responsible for any shortcomings of this paper.
} 
border. On the Venezuelan side, it is no less dangerous, especially near the border, but there are speakers living outside the Barí "mainland", thus making it possible to have contact with them. There are approximately 1,500 Barí in Venezuela; most speakers live in the town of Boksí, in the Municipio José María Semprún. Boksí can be reached only after an eight-hour boat ride, along the Catatumbo and Antray rivers. The course of the latter river, which divides Colombia and Venezuela, is controlled by various armed groups, among them the Venezuelan Army, and both guerrillas and paramilitary groups from Colombia. The latter allow only Indians into the area, so that field work in Boksí is impossible. The field work leading to this study was carried out in the city of Maracaibo.

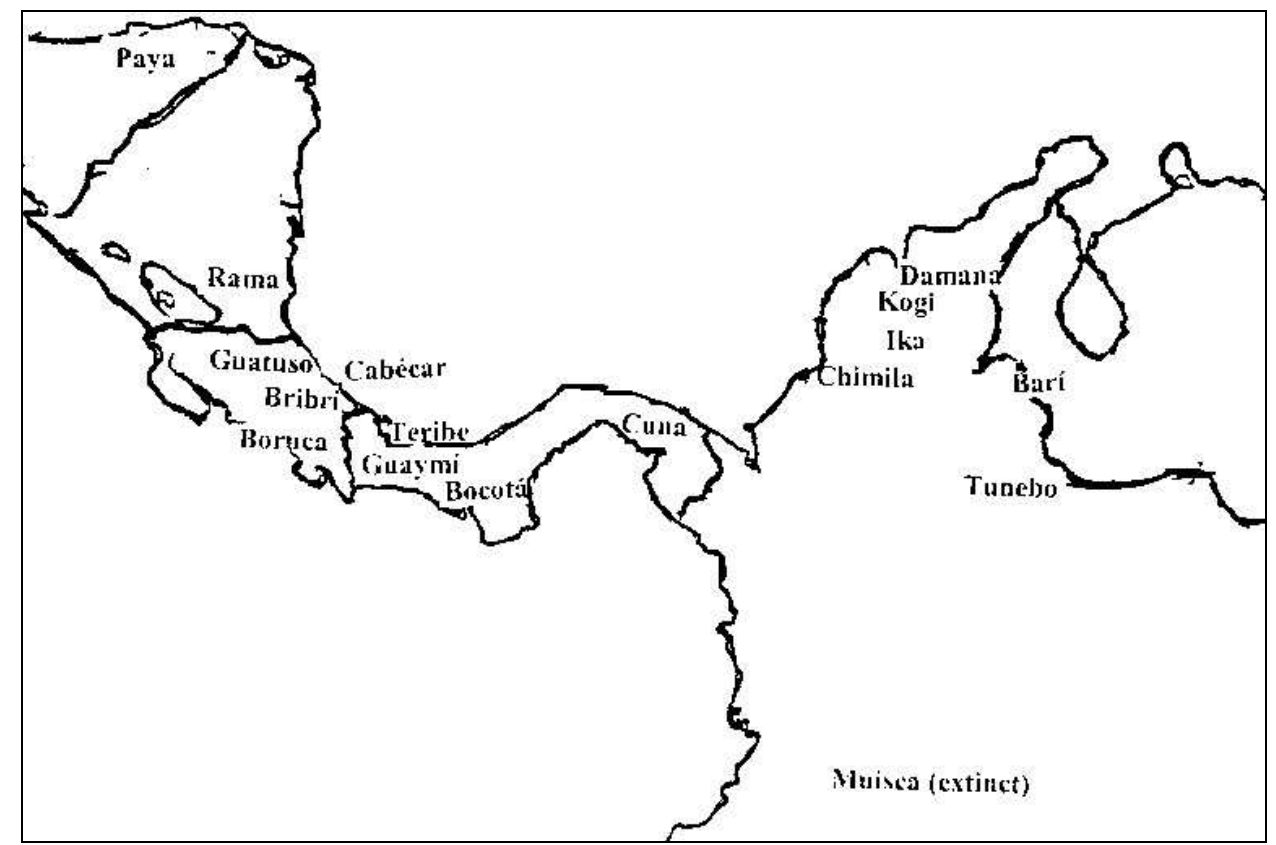

Fig. 1. Geographic distribution of the Chibchan languages and Bari

Acording to the language consultants, the Barí, who called themselves bari-ji $[\beta \alpha . \cup \mathrm{Pl} . \delta \mathrm{Zl}]$, bari-PL, have practically assimilated to the Venezuelan mainstream culture. Their houses are made of block and cement; most of them are practicing Catholics; they have some access to social services (state-run education, medicine, and, in some cases, electricity); and their clothing and diet are indistinguishable from that of the Venezuelan mainstream culture. Still, some of the ancient traditions persist, such as the existence of sukias $[1 . \cap \beta \alpha \varphi . \beta \alpha \varphi . \cup \beta \alpha) \varphi)]$, who heal both physically and spiritually, or the production of baskets made out of a liana called menda, as well as use of arrows (chi) and bows (aytakbarin) for hunting. Women weave the baskets; men make the arrows and bows.

Despite the high degree of assimilation, the language, which they refer to as baria $[\beta \alpha . \cup \mathrm{Pl} . \alpha]$ is at present not seriously endangered. There are some 150 monolingual speakers, mainly elderly people; children learn Barí as their first language; and the language is still a symbol of identity. Language loyalty is constantly being encouraged by the older people. There is a tendency, however, among young males (between the ages of 20 and 40) to use Spanish in their every day interaction, limiting the use of Barí to situations in which there are strangers around. Spanish is officially introduced in school and picked up through radio and television programs, although it appears that after watching a program, most people talk about it in Barí. As for dialectal variation, the 
consultants mention that the Bari from Colombia "speak like us, but they sing more", whence it can be inferred that differences may exist in terms of intonation and possibly phonetic realizations.

\section{Grammatical categories of Barí}

The main word classes of Barí are nouns and verbs, and to a lesser extent adjectives, adverbs and particles. In this respect, Barí does not differ from the languages of the Chibchan family.

\subsection{Nouns and nominal morphology}

Most Barí nouns are either bare roots or derivations with the nominalizer $-b \tilde{a} y$ ('for'). The former include such entities as proper nouns (Sabaseba 'God', Kãsosõ, Shalaba, etc.), places (Boksí, Saimadoyi, Bachichida, etc.), rivers (Ihkí, Dakda, Antray), as well as entities in general. As for derived nouns, -bãy, can be added to verbs to express the doer of the action, e.g. chueychuey 'sing' $+-b \tilde{a} y \rightarrow$ chueychueybãy 'singer', chidaseysey 'work' $+-b \tilde{a} y \rightarrow$ chidaseyseybãy 'worker'. It can also be added to perception verbs to form nouns expressing appliances: bisjiji $([\beta 1 \sigma . \cup \delta \mathrm{Zl} . \delta \mathrm{Zl}])$, 'see' + -bãy $\rightarrow$ bisjijibãy, 'T.V.set'; aanaynay 'hear' + -bãy $\rightarrow$ aanaynaybãy, 'radio'; abaybay 'talk' + -bãy $\rightarrow$ abaybaybãy, 'telephone'. Nouns are not marked for case in Barí.

Except for the use of numbers, the difference between mass and count nouns is grammatically irrelevant, as shown by the fact that quantifiers such as ikbé ('much', 'many') or kobakari ('little', 'a few'), are used with both types of nouns. Although Barí nouns can also be determined by numbers (intok, 'one', insami 'two', etc.), numbers do not specify class or shape in the context of quantification (the so called numeral classifiers). In this respect, Bari confirms the Chibchan geographic distribution of this phenomenon, according to which only the languages of Central America exhibit this type of noun classification. Cardinal numbers in Barí center on the concept of FIVE; in fact, the word for number 'five' is akdu ishkidã, which literally means 'a full hand'. The only numbers expressed by an "independent" lexeme are 1 to 3 ; thus

$\begin{array}{ll}\begin{array}{l}\text { intok } \\ \text { insami }\end{array} & \text { 'one' } \\ \text { te)tahko } & \text { 'two' } \\ \begin{array}{l}\text { ahdu ishkidã intokwa } w a \\ \text { ahdu ĩshidã }\end{array} & \text { 'four' (lit. 'a full hand, one non-existent') } \\ \end{array}$

The numbers 1,2 and 3 simply add to the number five expression to form the corresponding 6,7, and 8. As for numbers 9 and 10, again, the hand becomes the reference point; ahdu ĩshkidã ĩtomayno ishkidã intok wa (lit. 'a full hand plus a full hand, one nonexistent) and ahdu ĩshkidã itomayno ĩshkidã (lit. 'a full hand and full'), respectively. The hand-based system can go on and on. However, after ten (and sometimes after 5 already), speakers switch into Spanish.

As for plural marking, Barí is no exception to the Chibchan pattern, both paradigmatically and syntagmatically, that is, only nouns referring to human entities are marked for number (by the suffix $-j i[-\delta \mathrm{Zi}]),{ }^{3}$ and only the head of the NP is marked (in the presence of a quantifier the head is not marked, though, cf. (6b) or (7e), but see below);

\footnotetext{
${ }^{3}-j i$ can be used with non-human animate entities for personification purposes (e.g. in stories).
} 
in other words, there is no internal agreement. When plural marking occurs, a definite reading obtains. The same is true for quantifier phrases; insami atayda arombé means 'two angry men', but insami atayda-ji arombé means 'the two angry men'. Definiteness can also be expressed by possessive markers or possessive phrases in general, as well as by demonstratives. Markers of definiteness as such (e.g. articles, affixes) do not exist in Barí.

Demonstratives in Barí are organized in terms of three degrees of distance only; ${ }^{4}$ irabãy 'next to speaker', orabãy 'far from speaker', and orashu 'removed from speaker'. These three forms are undoubtely related to the corresponding adverbs: irãh $\tilde{a}$ 'here', orãha 'there', and orãhãshu 'over there'.

Barí is no exception to the most salient fearture of Chibchan nominal morphology, namely the existence of participant-highlighters, that is, markers that express the information-structure status of nouns, as either topics or foci, in addition to the expression of emphasis. The form hu marks topics, $h \tilde{a}$ expresses focus, and mãy emphasizes a noun regardless of, but also in addition to, its information-structure status; similarly, the marker $h \tilde{\imath}$ is used as anaphoric marker. More on this feature of Barí in 6., below.

The next nominal word class corresponds to personal pronouns. Barí pronouns distinguish number as well as switch reference, the latter only in the third person plural. Barí belongs to the half of the Chibchan languages without an inclusive/exclusive opposition. The Barí pronoun system is shown in (1). Personal pronouns are usually used for emphasis, as Barí is a pro-drop, head-marking language. Also, personal pronouns are invariable as to grammatical relations.

\begin{tabular}{cll}
\multicolumn{3}{c}{ Bari personal pronouns } \\
& 1. & nay \\
SG. & 2. & bay \\
& 3. & obãy \\
& 1. & chiji \\
PL. & 2. & biji \\
& 3SS. & obãyji \\
& 3DS. & Orachji
\end{tabular}

In the expression of possession the personal pronouns in (1) precede the possessum, which, in turn takes the prefix (C) $a$-; the consonant preceding the vowel represents a reduplication of the initial consonant of the pronouns expressing first and second person singular. Thus the noun bio ('woman'), when possessed becomes abio; if the possessor is first or second person singular the possessive noun phrase is nay nabio ('my wife') or bay babio ('your wife'), respectively. This rather exotic procedure is exclusive of Barí; most Chibchan languages make use of either a different set to express possession (however diachronically related it may be), as is the case with Kogi, Rama, Damana, or they use the same form (e.g. Boruca, Bribri, Guatuso), but not both. Expression of possession on the possessum is not common in Chibchan; in addition to Barí, only one language, Bocotá (Panama), makes use of this strategy.

Other pronoun sets include reflexive and interrogative pronouns. In terms of reflexive pronouns, the Chibchan languages can be classified on the basis of two parameters, indistinguishability of forms for the expression of reflexivity and reciprocity

\footnotetext{
${ }^{4}$ In other languages in the family, as in Cabécar (Costa Rica), demonstratives are also organized in terms of perception (e.g. [ \pm visible], and [ \pm audible].)
} 
(same form: Boruca, Guatuso; different form: Bribri, Teribe), and morphological status of the corresponding marker(s), as either free (Boruca, Teribe) or bound (Guatuso, Guaymí). Barí belongs to the group of languages that use the same form for reflexive and reciprocal situations, for all persons; the reflexive/reciprocal marker is the prefix $y a(k)$-:

(2a) Nay espeho ro ya-bra-ni

$1 \mathrm{SG}$ mirror in REFL-See.PRES -1SG

'I see myself in the mirror'

Obãyji yak-doi-drã

3PL RECIP-hit-3PL.PAST

'They hit each other/one another'

Interrogative pronouns, which always appear in sentence-initial position -except for the one expressing 'what', include aydou 'what', anõananna 'how', ababãyñana 'when', $a b a \tilde{a} \tilde{a}$ 'where', aydou aba 'why', ababãy 'which', and ãamãy 'who'; to express interrogative possession, the compound form obãy ãamãy 'whose' (lit. 'that who') has to be used.

\subsection{Verbs and verbal morphology}

Most verbs in Barí are bare roots, with very few compound forms. The Barí verb is marked for person, number, polarity and TAM. As most of its Colombian neighbors, Barí has a clearly identifiable tripartite tense system (past, present and future); the only aspectual distinction is the progressive, which is expressed periphrastically by the auxiliary verb ahji 'stand', 'be'. Barí deviates from most Chibchan languages of Colombia, however, in that it does not have the category of data source, also called "evidential".

As mentioned above, Barí is head-marking. The categories of person, number, polarity and tense are expressed in roughly the following order:

\section{OBJECT+ROOT $(+$ NEG $)+$ TENSE+PERSON.NUMBER}

The language is rather fusional, especially in the rightmost end of the string; in many cases, the degree of fusion in the expression of tense (especially in the case of negative polarity) borders on suppletion. Fusion can occur in the ROOT+TENSE (2a, above), in the TENSE+PERSON/NUMBER ( $2 b$, above), or even in the TENSE+POLARITY section of the string ( $5 \mathrm{~b}$, below). By expressing the object (either direct or indirect) on the verb, Barí sides with the Chibchan languages of Colombia. The object slot paradigm is provided in (3), and the subject slot in (4); how this pattern works in the expression of grammatical relations is explained in 5., below:

\begin{tabular}{lll} 
Object prefixes of Bari \\
& \multicolumn{2}{c}{ direct object } \\
& 1. & la- \\
SG. & 2. & $b a-$ \\
& 3 & $a-\sim \varnothing-$ \\
& 1. & $c h i-$ \\
PL. & 2. & $b i-$ \\
& 3. & $i-$
\end{tabular}

\begin{tabular}{c} 
indirect object \\
\hline$l i-$ \\
$b i-$ \\
$i-$ \\
$c h i-$ \\
$b i-$ \\
$i-$
\end{tabular}


(4)

$$
\begin{aligned}
& \text { Subject suffixes of Bari (paradigm of the present tense, regular verbs only) } \\
& \text { 1. }-n i \\
& \text { SG. } \quad 2 . \quad-m i \\
& 3-s \tilde{a} y \\
& \text { 1. }-\operatorname{ch} \tilde{a} \\
& \text { PL. 2. } \quad \text { 2. mia } \\
& \text { 3. }- \text { drin } \sim \operatorname{sãy}
\end{aligned}
$$

Switch reference is expressed by the free forms listed in (1), not by verb inflection. As for negative polarity, the negative suffix (as opposed to the unmarked affirmative) $-s h$ (and allomorphs) is usually identifiable before, as in (5b) or after the subject suffix (depending on construction type), as in (5c): ${ }^{5}$

(5a) Nay ba-kayasra-ni

1SG 2SG-wait.PRES-1SG

'I wait for you'

(5b) Nay ba-kag-bishro-ni

1SG 2SG-wait-PRES.NEG-1SG

'I don't wait for you'

(5c) Nay jiru ba-la-kag-bishi

$1 \mathrm{SG}$ yesterday 2SG-1SG-wait-PAST.NEG

'I didn't wait for you yesterday'

\subsection{Other word classes}

After nouns and verbs, adjectives and adverbs represent a secondary set of word classes from the point of view of quantity of adjectival and adverbial lexemes. Adjectival roots comprise those expressing qualities (isé 'good, nice, pretty', atkà 'bad, ugly'), size (istodou 'little', abi 'big'), states (dó 'young', sakdou 'old', ahdo 'new', suksari 'happy', tetá 'cold'), and colors (bé 'black', batchi 'white', tàktà 'green', moàay 'brown, red', dohkó 'light', sé)) 'dark'; other colors are expressed by composition). As for adverbial lexemes, three main groups can be identified, location (irãhã 'here', rãhã 'there', ischikiyá 'far'), time (ahkak 'today', jiru 'yesterday', shya 'tomorrow', tukda 'later', aarire 'always', darin 'never'), and manner (kõãyatchi 'fast', sámay 'slowly').

Postpositions complete the inventory of the main word classes of Barí. The former include $a h k i$ 'for', 'to', used for dative noun phrases; $a b a$ 'to', 'for', used for pronominal direct objects as well as for purposive subordinate clauses; kãy 'with' a comitative form

\footnotetext{
${ }^{5}$ An apparent cognate of this form and pattern exists in Boruca - shi and Tunebo - $t i$. Both free and (invariable) bound negation are equally distributed across the Chibchan family. Barí belongs to the group that expresses negation by bound morphology, with the peculiarity that its negative morphemes "decline" for TAM, cf. (5b-c). One other language, Paya (Honduras) behaves in a like manner (cf. HOLT 1999).

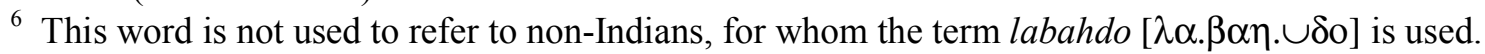


opposed to the instrumental âha 'with'; ${ }^{7}$ plus some other locative forms such as ro 'in, at', nõ 'from', aktokakda 'behind', rãhã 'inside, onto', bo 'on, above', and mãydu 'because of'. As in most Chibchan languages, asyndetic constructions abound; a few conjunctions exist nevertheless, among them inka 'and', kenemba 'then', anĩ ĩ 'thereafter', enikã 'until'.

\section{Word order}

4.1. The main clause

The order of constituents in the main affirmative, declarative clause is SOV (6a), although there is a tendency among young speakers to use an SVO (6b) order. Whether this alternative is due to contact with Spanish or Guajiro (Arawak), or both, exceeds the scope of this paper:

(6a) Nay shima aksra-ni

1SG water drink.PRES-1SG

'I drink water'
(6b) Nay bisd-r-un insami buktray
$1 \mathrm{SG}$ see.PAST.1SG-PAST two Guajiro
'I saw two Guajiros' 8

Like other Chibchan languages (e.g. Guatuso, Damana), Barí by virtue of its headmarking pattern, allows other alternative orders, which result from the interaction of verbal morphology and the status of NPs as either full or pronominal. Thus a sentence like (6c), $\mathrm{SOV}$, can be expressed as (6d) OV-s and (6e), S o-V, or even (6f), o-V-s (recall that third person singular object prefix is $\varnothing$ ):

(6c) Nay akseyseybãy akshi-r-õ

$1 \mathrm{SG}$ glass buy-1SG-PAST

'I bought the glass'

(6d) Akseyseybãy akshi-r-õ

glass buy-1SG-PAST

'I bought the glass'

(6e) Nay Øakshi-r-õ

$1 \mathrm{SG}$ 3SG-buy-1SG-PAST

'I bought it'

(6f) $\varnothing$-akshi-r-õ

3SG-buy-1SG-PAST

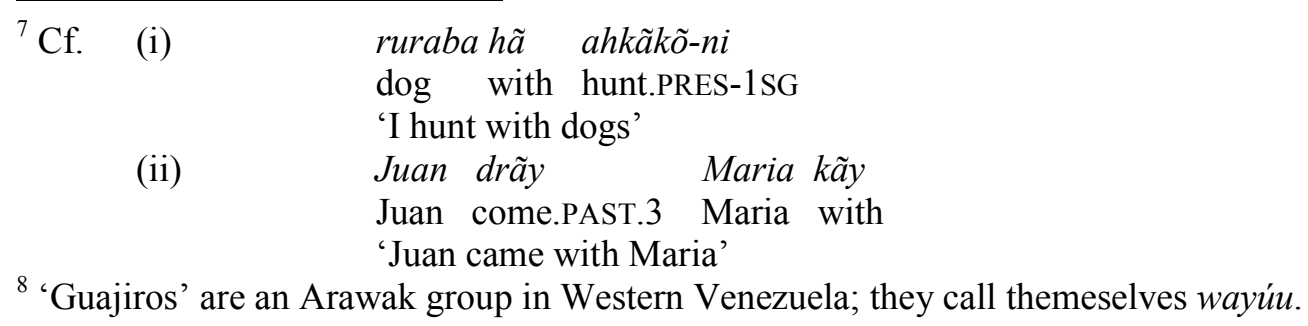


'I bought it'

As elsewhere in the family, these orders are discourse-run, with the "full pattern" used for discourse-opening and the other orders reserved for running discourse, the OV-s order is also used for introducing new participants in the O-role. There are various other orders in the main clause, which depend on the expression of grammatical relations; these will be addressed in 5 .

\subsection{The noun phrase}

The constituents of the Barí noun phrase are both prenominal and postnominal. The former include possessors (both nominal and pronominal) in possessive noun phrases (7a) and $(7 b)$, and demonstratives $(7 \mathrm{c})$ :

(7a) Juan a-biobãy

Juan POSS-woman

'Juan's wife'

(7b) Nay n-a-biobãy

$1 \mathrm{SG}$ 1SG-POSS-woman

'My wife'

(7c) Irabãy $k a$

DEM house

'This house'

Postnominal members of the noun phrase include adjectives (7d), quantifiers (7e) (see below about numbers), and participant-highlighters (7f):

(7d) Bahtro bé

book dirty

'Dirty book'

(7e) Kabayo ikbé

horse many

'Many horses'
Saabaseeba hü i-bag-ra
atka obik-bari-mãy ahki:
God
TOP 3.dat-say-PAST.3SG
ugly
sick-person-REL to

'God said to the person who was horribly sick:'

In the case of adjectives, attribution and predication can be distinguished by the use of the copular root ahji; thus (8a) is the predicative version of (7d):
Bahtro li-ra-b-õ-mãy
bé obi-k-ahji
book 1DAT-give-2SG-PAST-REL
dirty stand-3SG.PRES-stand
'The book you gave me is dirty'

The use of the copular construction, however, alternates with verbless predications, so that sometimes it is difficult, on purely formal grounds to distinguish between attribution and predication; (8b) has also a predicative reading, 'this dog of the chief's is angry'. 
(8b) Iña irabãy ruraba arombe

Chief DEM dog angry

'This angry dog of the chief'

Numbers represent a special constituent of the noun phrase in terms of word order. They can precede (6b, above) and follow (9a, below) the head, in what appears to be a sort of quantifier float; this view is reinforced by the fact that the number can be separated by the head by other linguistic material, as in $(9 b)$ :

(9a) Nay ruraba insami bisd-run

$1 \mathrm{SG}$ dog two see-PAST.1SG

'I saw two dogs'

(9b) Nay intok bisd-run buktray

1SG one see-PAST.1SG Guajiro

'I saw one Guajiro'

(9b) could be analyzed as an instance of SVO order with quantifier float, or as and instance of SOV order, where the number one (intok) is syntactically the head of the object noun phrase and buktray ('Guajiro') is a sort of adjectival object complement. In any case, the main feature remains, namely that numbers have no fixed position vis-à-vis the head of the noun phrase. The structure of the Barí noun phrase can thus be represented as in (10):

$$
{ }_{\mathrm{NP}}\left[(\text { Poss })\left(\text { Dem) }\left\{\mathrm{i}_{\mathrm{i}}(\mathrm{Num})_{\mathrm{ii}}\left[\mathbf{N}(\text { Adj) }]_{\mathrm{i}}(\mathrm{Num})\right]_{\mathrm{ii}}\right\} \text { (Quant) (P.H.) }\right]_{\mathrm{NP}}\right.
$$

where $\mathrm{N}$ stands for the only obligatory member of the NP, optionally preceded by either a possessor, a demonstrative, or both, and followed by either a quantifier, a marker of information structure status, or both. The braces represent the two possibilities in terms of the position of numbers in the noun phrase, either before the noun, as in (6b) or after it, in which case the adjective takes precedence over it, as in (8b), above.

\subsection{The verb phrase}

As pointed out repeatedly, Bari is head-marking. Hence the only obligatory constituent of a verb phrase is the verb. The minimal expression can obviously be enlarged depending on discourse needs; thus (11) can have at least the replies in (12):

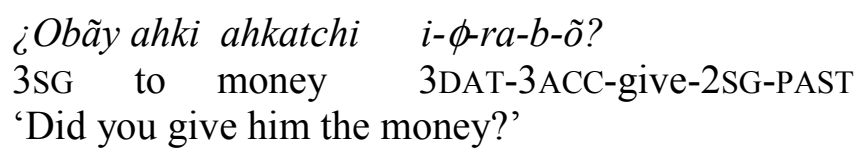

'Did you give him the money?'

(12a) $I-\phi-r a-r-\tilde{o}$

3DAT-3ACC-give-1SG-PAST

'I gave it to him'

(12b) Akatchi i- $\phi-r a-r-\tilde{o}$

money 3DAT-3ACC-give-1SG-PAST 
'I gave him (the) money'

(Nay) jiru akatchi i- $\phi-r a-r-\tilde{o}$
(1SG) yesterday money 3DAT-3ACC-give-1SG-PAST
'I gave him (the) money yesterday'

(12a-c) reveal a fixed word order pattern, in which the object is always adjacent to the verb; in the above examples, it precedes the head, but in the scarce (S)VO constructions it follows it; still, the main feature remains: object and verb constitute an indivisible unit. The boundary of the verb phrase is marked by the presence of adverbial information (adverbs or postpositional phrases in adverbial function); in fact, in (12c) the adverb jiru can follow the verb phrase just as well (be it in the SOV or in the SVO order), but it may not appear between the verb and the object. Only in highly marked constructions, like (13) is this unity broken; the OSV order in (13) was most of the time rendered as a cleft construction in Spanish:

\section{(13) Orabãy ka bay b-a-tayda bab-ãy \\ DEM house $1 \mathrm{SG}$ 1SG-POSS-father build-PAST.3SG \\ 'That's the house that my father built' (lit. 'that house my father built')}

As for indirect object noun phrases, these normally follow the verb, as in (14a), though on occasion, in fact extremely sporadically, they may appear between the direct object and the verb (14b); it goes without saying that in absence of an overt direct object noun phrase, the contiguity restriction becomes non-applicable (14c):
Nay bahtro bi-ra-ni
bay ahki
$1 \mathrm{SG}$ book 2DAT-give.PRES-1SG 2SG to
'I give you the book'

(14b) Nay bahtro bay ahki bi-ra-ni

$1 \mathrm{SG}$ book $2 \mathrm{SG}$ to 2SG-give.PRES-1SG

'I give you the book'

(14c) Nay bi-ra-ni

$1 \mathrm{SG}$ 2SG-give.PRES-1SG

'I give (it to) you'

The most common configuration of a trivalent structure in Barí, however, is that in (12b), where the object is overtly expressed and the other two participants (dative and subject) are coded in the verb.

\section{Grammatical relations}

The combination of three coding strategies, constituent order, the head-marking pattern, and direct marking (in the case of dative noun phrases and pronominal object phrases) reveal the relevance the following grammatical relations in Barí, subject, object and dative. Oblique relations include instrumental, comitative, and locative phrases.

\subsection{Subject}


Subject noun phrases can be identified a. morphologically, by their indexation on the verb (cf. 3.2.); and b. syntactically, by their position in the sentence, which in most cases is sentence-initial; and by certain syntactic processes which require the existence of the category of subject, such as two-verb clauses (15) or reflexivization (2a-b, above) and possessive reflexivization, also called external possession (16):

Jabon akshi-r-õ mata-duy aba

soap buy-1SG-PAST clothes-wash for

'I bought soap (in order) to wash clothes' (lit. 'for cloth-washing')

(16) Bay akkobe yak-ko-b-õ

2SG tongue REFL-bite-2SG-PAST

'You bit your tongue'

In (15) two verbs are coordinated by virtue of their sharing the same referent, namely a constituent fulfilling a specific syntactic relation, that of subject. Similarly, in (16) the expression of possession is made possible by the coreference existing between the first $\mathrm{NP}$ in the sentence and the reflexive prefix; that NP is the subject of the clause.

The morphosyntactic expression of subjecthood in Barí clearly follows a nominative-accusative pattern. Subject noun phrases, whether lexical or pronominal are treated equally regardless of the transitivity of the verb, as can be seen in the following examples:

(17a) Bay kabru-mi ikbé

2SG sleep.PRESS-2SG much

'You sleep too much!'

(17b) ¿Aydo aba bay kabayo (aba) dra-mi?

why 2SG horse (to) hit.PRES.2SG

'Why do you hit the horse?

(17c) Kabayo kabi-sãy

horse sleep.PRES-3SG

'The horse is sleeping'

Both cross-reference and morphological coding of the participants clearly reveal equal treatment of $S$ (intransitive subject) and A (agent of transitive clause). In fact, the optional postposition in (17b) hints at an opposition between $\mathrm{S}$ and $\mathrm{A}$ against $\mathrm{O}$ (object of a transitive clause).

In clauses with no lexical noun phrases, the accusative pattern allows the identification of participants in those cases in which only one of them is expressed:

(18a) Nay ba-dra-ni

1SG 2SG-hit.PRES-1SG

'I hit you'

(18b) Nay lahdra-mi

1SG 1SG-hit.PRES-2SG 
'You hit me'

(19a) Bay lahdra-mi

2SG 1SG-hit.PRES-2SG

'You hit me'

(19b) Bay bahdra-ni

2SG 2SG-hit.PRES-1SG

'I hit you'

The role of the overtly expressed participant has to be sought in the verb morphology and syntactic structure. In the (a) examples, the pronominal NP finds itself outside the verb phrase, while in the (b) examples it is an integral part of it. The difference between (18a) and (18b) and that between (19a) and (19b) is thus one of information structure, concretely unmarked focus. The former are agent-oriented (or agent-focus), whereas the latter are patient-oriented (or patient-focus). This type of alignment is commonplace in the Chibchan languages, especially in those of Colombia (and Guatuso in Central America).

\subsection{Object}

The (direct) object in Barí can be identified both morphologically (by means of the object prefixed listed in (3), above), and positionally; as mentioned in 4.3., the object NP and the verb form a cohesive unit, so that in most cases any NP in preverbal position can be safely analyzed as the object of the clause. Object noun phrases can also be made "more explicit" by means of the postposition aba (cf. (17b), above. Thus in cases in which the object is moved from its preverbal position, the postpositional phrase will identifiy the noun phrase as object:

$$
\begin{array}{lll}
\text { Obãy jiru } & \text { chi-doyko-sãy chiji aba } \\
\text { 3SG yesterday } & \text { 1PL-hit.PAST-3SG } & \text { 1PL to } \\
\text { 'He hit us yesterday' } &
\end{array}
$$

Again, presence of a postpositional verb phrase is a matter of information-structure status.

\subsection{Dative}

Like objects, dative noun phrases can be identified by a. verb morphology and/or by the overt expression of the dative participant as a postpositional noun phrase; in this case the postposition used is ahki; again, overt expression of a dative participant has to do with information-structure strategies:

$$
\begin{array}{lll}
\text { Nay ruraba } & \text { bi-ra-ni } & \text { (bay ahki) } \\
1 \mathrm{SG} \text { dog } & \text { 2DAT-give.PRES-1SG } & \text { (2SG to) } \\
\text { 'I give you a dog' ('I gave a dog TO YOU') }
\end{array}
$$

\subsection{Obliques}

Oblique relations are expressed by postpositional phrases. Among the semantic roles expressed by oblique phrases are INSTRUMENTAL, by the postposition $\tilde{a} h \tilde{a}$, 
COMITATIVE, by the postposition $k \tilde{a} y$, and various LOCATIVE relations by the postpositions listed in 3.3. A common denominator of these postpositional phrases is the tendency to appear in sentence-final position. There appear to be no syntactic processes involving oblique noun phrases.

\section{Participant-highlighting}

Participant-highlighting is that domain of the information-structure component of sentence grammar which is concerned with the formal, grammaticalized encoding of the pragmatic states of participants in non-canonical configurations (cf. QUESADA 1999a). That is, participant-highlighting has to do primarily with marked (re-)activating, topicalizing, focalizing mechanisms applying at the sentence level; this restriction to marked constructions has to do with the fact that these constructions most clearly reveal a mechanism of separation of "the REFERRING function of noun phrases from the RELATIONAL role their denotata play as arguments in a proposition" (LAMBRECHT 1994: 184). Referents are highlighted when their referring function is separated from the relational role. This does not mean that activation can only be achieved through special structural means. Bare mention is an activating mechanism. However, from the point of view of marked foregrounding, only those (re-) activating mechanisms requiring sign material (including word order) are relevant. Now, in the case of Barí, to the extent that the various word order patterns correlate with information structure status of participants, the various word order patterns can be regarded as representing syntacticized mechanisms of information-structure status encoding; and as such, they can be regarded as participant-highlighting mechanisms, albeit not totally "marked" ones. Thus, although distinction between marked and unmarked highlighting mechanisms can be established, it should be borne in mind that in Bari that distinction is not clear-cut. The main features of participant-highlighting in Barí are word order, and direct marking on the NP, as

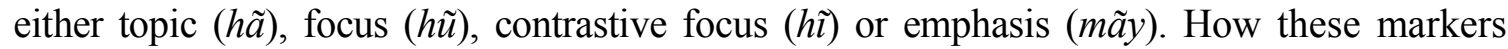
function in actual language performance can be better illustrated by means of a text. The following is a description of the process of marrying; it was produced by Mr. Leonardo Okiano.

$$
\begin{aligned}
& \text { ¿Anoãnanna bio burí? } \\
& \text { How woman marry }
\end{aligned}
$$

$$
\text { Bio ka kãy hũ a-tayda ahki i-b-ay bakrangnike }
$$

Woman house with TOP POSS-father to 3DAT-ask-PRES.3SG marry yes

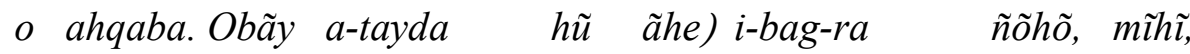

$$
\begin{aligned}
& \text { or no. } 3 \mathrm{SG} \text { POSS-father FOC yes 3DAT-say-3SG maybe, OK, }
\end{aligned}
$$$$
\text { burí unikenembà. Asashi hũ, obãy a-biobay skãy a-tayda ah-ka }
$$

marry then. Boy FOC, 3SG POSS- woman toward POSS-father 3POSS-house

$\begin{array}{llllll}\text { ro } & \text { yai-taqbai-sãy; } & \text { mimainahã atayda hã } & \text { yai-kasainai-nay chida } \\ \text { in } & \text { REFL-stay-3SG; } & \text { but } & \text { father TOP REFL-leave-3SG work }\end{array}$

ahki inka a-biobay iseaba. Anīhĩunikenembà a-tayda hũ ãhe) to so that POSS-woman pretty. Go then POSS-father FOC yes

mimainahãariré rikenembà, ini-mi hũ ka saka-mi nera a-biobay aba. but long time then, go-2SG FOC house build-2SG ? POSS-woman for. 


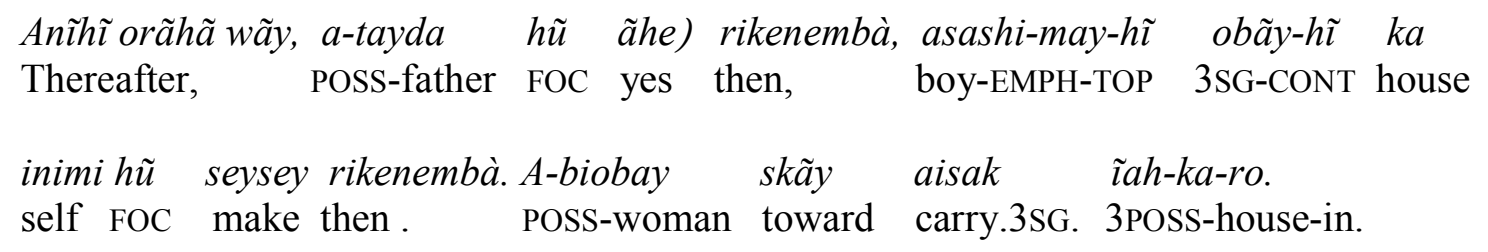

\section{How a woman gets married}

The woman asks her father whether she can get married or not. If the father agrees, she may get married. The bridegroom then goes to the woman's father's house and stays there. But the father goes to work (in order to support the girl), so the girl gets pretty. Though the father may agree with the marriage, the girl has to wait until the man builds a house for her. Once the house is built, the father consents to the marriage, the man himself has to build the house so he can take the woman in there (lit. 'to HIS house').

The text reveals two basic aspects about participant-highlighting strategies. First, it is up to the speaker when a participant's information-structure role is to be highlighted (that is, by means of marked mechanisms). Secondly, the information-structure status is independent of syntactic function (or grammatical relations). Thus, the opening sentence has a subject marked as focus and the sentences before last has a peripheral participant marked as contrastive focus ('his house'). In addition, the fact that a participant's information-structure status may be signaled does not preclude the fact that it may additionally be emphasized (double highlighting), as is the case with 'the boy' in the sentence before last (asashi-may-hĩ). This admittedly brief overview of the grammar of participant-highlighting clearly shows that in this aspect of functional grammar, Bari behaves like a typical language not only of the Chibchan family but also of the Intermediate Area, and similar to some Amazonian languages (cf. SOARES \& QUESADA 1999).

\section{Conclusion}

The previous description of the structure of Barí allows the conclusion that this language, despite its peripheral status remains loyal to its Chibchan features, siding as one could expect, with the languages of Colombia. This conclusion can be made more explicit in terms of comparison parameters such as grammatical categories and structural (morphological) features. For instance, in the nominal dimension it exhibits all common Chibchan traits such as plural-marking, participant-highlighters, and possessive markers, but, like the Chibchan languages of Colombia, it does not have numeral quantifiers. In addition, like all Chibchan languages, it has no markers of definiteness. In the verbal dimension, this tense language exhibits a rich head-marking pattern, which includes even indexing of dative participants. Again, this is the typical case scenario in the Chibchan languages of Colombia. It can thus be safely concluded that the Chibchan southern periphery has remained in principle immune to its neighborhood. Whether that is the case in the northern end (with Paya in Honduras) remains an open question to be investigated in the future.

\section{References}


Constenla, Adolfo. (1991): Las lenguas del Área Intermedia. San José: Editorial Universidad de Costa Rica.

Holt, Dennis. (1999): Pech (Paya). Munich: Lincom-Europa.

KIPPER, Anna. (1965) : "Vocabulaire Bari des Indiens Motilon de la Sierra de Perijá", in Journal de la Société des Américanistes. 335-347.

Korombara, Nubia. (1993) : El orden de las palabras en la oración simple de la lengua barí. Universidad del Zulia (Maracaibo). Licenciatura Thesis.

LAMBRECHT, Knud. (1994): Information structure and sentence form. Cambridge: Cambridge University Press.

PAYNE, Thomas. (1997) : Describing Morphosyntax. Cambridge: Cambridge University Press.

QuesaDA, J. Diego. (2000): A Grammar of Teribe. Munich: Lincom-Europa.

(1999a): Chibchan: with special reference to participant-highlighting, in Linguistic Typology 3. 2, 209-258.

(1999b): Ergativity in Chibchan, in Sprachtypologie und Universalienforschung 52.1, 22-51.

(1999c): "Marcación intermitente en las lenguas chibchas: economía funcional y gramática del discurso". Paper read at the I Congreso de Lenguas Indígenas de Suramérica. Universidad Ricardo Palma, Lima.

SoARES, Marília F. \& QuesAdA, J. Diego. (1999): Participant-highlighting in two linguistic areas of the Americas. Proceedings of the IV Workshop on Constituency and Structure of the Languages of the Americas. University of British Columbia Working Papers in Linguistics 2, 117-129.

VIVAS, Ramón E. \& OBREGÓN, Hugo. (1989): "Investigaciones en torno a la lengua barí, su sistema fonético". Venezuela Misionera 528, 195-20.

\section{Abbreviations}

$1,2,3$ grammatical person

ACC accusative

CONT contrastive focus

DAT dative

DEM demonstrative

EMPH emphasis marker

FOC focus

NEG negative polarity

PAST past tense

P.H. participant highlighter

PL plural

$\begin{array}{ll}\text { POSS } & \text { possessive marker } \\ \text { PRES } & \text { present tense } \\ \text { QUANT } & \text { quantifier } \\ \text { RECIP } & \text { reciprocal } \\ \text { REFL } & \text { reflexive } \\ \text { REL } & \text { relativizer } \\ \text { SG } & \text { singular } \\ \text { TOP } & \text { topic }\end{array}$

POSS possessive marker

reciprocal

reflexive

relativizer

topic 